\title{
Sickle cell disease: a case report of renal amyloidosis
}

\author{
Ann Bugeja ${ }^{1 *} \mathbb{D}$, Paula Blanco², Edward G. Clark and Manish M. Sood ${ }^{1}$
}

\begin{abstract}
Background: The development of proteinuria and reduced glomerular filtration rate is associated with higher mortality among patients with sickle cell disease (SCD). AA amyloidosis, also associated with increased mortality, in SCD is rare. We present a case of a woman with homozygous sickle cell disease with nephrotic syndrome and antibodies to double stranded DNA without clinical features of systemic lupus erythematosus. Kidney biopsy reveals AA amyloidosis and is the first report of concomitant AA amyloidosis with antibodies to double stranded DNA in SCD.

Case presentation: A 40-year-old Central African woman with homozygous sickle cell disease and history of vaso-occlusive pain crises undergoes kidney biopsy for nephrotic-range proteinuria. Kidney biopsy reveals AA type amyloidosis, which is a rare manifestation of SCD in the kidney. Her anemia worsens with an ACE inhibitor, initiated to reduce proteinuria and limit GFR decline, so it was discontinued. Hydroxyurea, shown to decrease the frequency of vaso-occlusive crises and lower proteinuria, was subsequently initiated but then discontinued due to worsening anemia. Unfortunately, her glomerular filtration rate worsens.

Conclusions: AA amyloidosis and antibodies to double stranded DNA can occur in sickle cell disease. ACE inhibition and hydroxyurea decrease proteinuria so they may limit progression of chronic kidney disease. Hydroxyurea also decreases frequency of vaso-occlusive pain crises so it might be helpful in limiting progression of renal AA amyloidosis. However, further studies are needed to determine optimal treatment strategies for AA amyloidosis in sickle cell disease.
\end{abstract}

Keywords: Proteinuria, Sickle cell, Amyloidosis, Chronic kidney disease

\section{Background}

Sickle cell disease frequently affects kidney structure and function. Early glomerular hyperfiltration can lead to glomerular hypertrophy then proteinuria [1] with glomerulosclerosis and decreased glomerular filtration rate (GFR) in sickle cell disease [1]. Focal segmental glomerulosclerosis is the most frequent glomerulopathy seen in patients with sickle cell disease [1]. Membranoproliferative glomerulonephritis and thrombotic microangiopathy have also been described [1]. However, nephrotic-range proteinuria has been only noted in approximately $4 \%$ of patients with proteinuria and is associated with reduced GFR and increased mortality [1]. We present the first report of concomitant AA amyloidosis with antibodies to double stranded DNA in SCD.

\footnotetext{
* Correspondence: abugeja@toh.ca

${ }^{1}$ Division of Nephrology, Department of Medicine, The Ottawa Hospital and University of Ottawa, Riverside Campus, 1967 Riverside Drive, Ottawa, ON K1H 7W9, Canada

Full list of author information is available at the end of the article
}

\section{Case presentation}

Clinical history and initial laboratory data

A 40-year-old Central African woman with homozygous sickle cell disease was referred for evaluation of proteinuria. During the past 5 years, her serum creatinine $(\mathrm{Scr})$ level ranged from $0.35 \mathrm{mg} / \mathrm{dL}-0.70 \mathrm{mg} / \mathrm{dL}$ (corresponding to estimated GFR of $126-164 \mathrm{~mL} / \mathrm{min} / 1.73 \mathrm{~m}^{2}$, using the corrected CKD-EPI [Chronic Kidney Disease Epidemiology Collaboration] equation for race. Five years prior to nephrology presentation, her urine albumin to creatinine ratio (ACR) was $610 \mathrm{mg} / \mathrm{g} ; 2$ months ago, it was $7779 \mathrm{mg} / \mathrm{g}$.

At nephrology evaluation, she reported multiple vaso-occlusive pain crises as a child. She had a vasoocclusive pain crisis and required red cell transfusion following a therapeutic abortion 5 years ago. Six emergency room visits followed for vaso-occlusive pain crises. She has proliferative sickle cell retinopathy and restrictive lung disease. Folic acid was her only medication and she took acetaminophen for a vaso-occlusive pain crisis 2 months ago. 
Her physical examination revealed a non-obese woman with a blood pressure of 120/70 $\mathrm{mmHg}$ and heart rate 94 beats per minute and regular. She did not have any flow murmurs on precordial examination and she had bilateral ankle edema. The rest of her physical examination was normal. Laboratory investigations (Table 1) revealed: Scr $0.94 \mathrm{mg} / \mathrm{dL}$, estimated GFR, $88 \mathrm{~mL} / \mathrm{min} / 1.73 \mathrm{~m}^{2}$ and hemoglobin $64 \mathrm{~g} / \mathrm{L}$. Urinalysis showed $2+$ blood, $3+$ protein and urine microscopy revealed 5-30 red blood cells without casts. Urine ACR is $6089 \mathrm{mg} / \mathrm{g}$. Serologic workup revealed an anti-nuclear antibody titer of 1:320 and anti-double stranded DNA titer $72 \mathrm{IU} / \mathrm{ml}$ by ELISA. Investigations for sarcoidosis were not performed. Abdominal

Table 1 Laboratory results at initial nephrology visit

\begin{tabular}{|c|c|c|}
\hline Parameter & Value & Reference Range \\
\hline \multicolumn{3}{|l|}{ Blood } \\
\hline Creatinine (mg/dL) & 0.90 & $0.25-0.85$ \\
\hline eGFR $\left(\mathrm{ml} / \mathrm{min}\right.$ per $\left.\left.1.73 \mathrm{~m}^{2}\right)\right)$ & 88 & $\geq 90$ \\
\hline Sodium (mEq/L) & 141 & $135-145$ \\
\hline Potassium (mEq/L) & 3.0 & $3.5-5.0$ \\
\hline Chloride (mEq/L) & 106 & $98-107$ \\
\hline Corrected serum calcium (mg/dL) & 10.0 & $8.5-10.1$ \\
\hline Albumin $(\mathrm{g} / \mathrm{dl})$ & 2.2 & $3.4-4.6$ \\
\hline Hemoglobin (g/dl) & 64 & $115-155$ \\
\hline Mean corpuscular volume (fL) & 69 & $80-100$ \\
\hline Hematocrit (\%) & 20 & $38-50$ \\
\hline Reticulocyte count (\%) & 38 & $0.5-1.5$ \\
\hline Lactate dehydrogenase (U/L) & 258 & $100-205$ \\
\hline Glucose, fasting (mg/dl) & 95 & $72-198$ \\
\hline Cholesterol, total (mg/dl) & 213 & $135-201$ \\
\hline LDL (mg/dl) & 135 & 135-193 \\
\hline Triglycerides (mg/dl) & 163 & $\leq 177$ \\
\hline $\mathrm{HDL}(\mathrm{mg} / \mathrm{dl})$ & 46 & $\geq 50$ \\
\hline C3 (mg/dl) & 142 & $90-180$ \\
\hline $\mathrm{C} 4(\mathrm{mg} / \mathrm{dl})$ & 20 & $10-40$ \\
\hline Hepatitis B surface antigen & negative & negative \\
\hline Hepatitis C surface antibody & negative & negative \\
\hline HIV & negative & negative \\
\hline Anti-nuclear antibody & $1: 320$ & negative \\
\hline Anti-double stranded DNA (IU/ml) & 72 & $<30$ \\
\hline Serum monoclonal protein & Negative & negative \\
\hline \multicolumn{3}{|l|}{ Urine } \\
\hline Red blood cell (/HPF) & $5-30$ & $0-2$ \\
\hline Albumin/creatinine ratio (mg/g) & 6089 & $\leq 18$ \\
\hline Monoclonal protein & Negative & negative \\
\hline
\end{tabular}

eGFR estimated glomerular filtration rate by CKD-epi equation, $L D L$ low density lipoprotein, $H D L$ high-density lipoprotein, HIV human immunodeficiency virus, HPF high power field ultrasonography revealed that the length of both kidneys was $12 \mathrm{~cm}$. She consented to kidney biopsy under ultrasonography guidance to diagnose the cause of her nephrotic syndrome.

\section{Kidney biopsy results}

The kidney biopsy specimen contained up to 15 glomeruli, 3 of which were globally sclerosed. There was no significant glomerular hypertrophy. Most glomeruli showed prominent nodular accumulation of amorphous, eosinophilic, weakly PAS positive, non-argyrophilic (staining properties of amyloid) material (Fig. 1a, arrow). Congo red stain confirmed that this material exhibited the characteristic apple green birefringence of amyloid when examined under polarized light. Amyloid was type AA as demonstrated by immunohistochemistry. Amyloid extensively extended into arterioles (Fig. 1b, arrow). There was patchy but significant deposition of amyloid in the walls of tubules with associated epithelial injury. Prussian blue stain for iron, often seen in tubular epithelial cells in sickle cell nephropathy, was negative. There was mild interstitial fibrosis and tubular atrophy. Arteries showed wall thickening by amyloid as well as multilayering of the internal elastic lamina. Immunofluorescence showed weak granular non-specific glomerular staining for IgM and C3. There was no staining for IgG, IgA, or $\kappa$ and $\lambda$ light chains. Electron microscopy showed deposition of non-branching randomly arranged fibrils, consistent with amyloid, predominantly in mesangial areas but also along and permeating the glomerular basement membrane. There was effacement of foot processes overlying areas with amyloid deposition (Fig. 1c). A diagnosis of AA type amyloidosis was made.

\section{Clinical follow-up}

Perindopril $2 \mathrm{mg}$ once daily was initiated to lower proteinuria, but there was concern that it was exacerbating her anemia. Perindopril was discontinued when her hemoglobin had fallen to $47 \mathrm{~g} / \mathrm{L}$ and a new anti- $\mathrm{U}$ antibody was detected, making red cell transfusion challenging. She was subsequently admitted to hospital with acute chest syndrome and mild pulmonary hypertension was noted on two-dimensional echocardiogram. Hydroxyurea was later initiated when her hemoglobin level was $61 \mathrm{~g} / \mathrm{L}$ and discontinued 2 months later when her hemoglobin had fallen to $43 \mathrm{~g} / \mathrm{L}$, due to concern that hydroxyurea may have worsened her anemia. At the last available follow-up, 1 year after initial nephrology presentation, her Scr is $1.47 \mathrm{mg} / \mathrm{dL}$ (estimated GFR $51 \mathrm{~mL} / \mathrm{min} / 1.73 \mathrm{~m}^{2}$ ), urine ACR $7965 \mathrm{mg} / \mathrm{g}$ and hemoglobin $66 \mathrm{~g} / \mathrm{L}$. Resting blood pressure is 129/ $75 \mathrm{mmHg}$. She does not have clinical features of systemic lupus erythematosus (SLE). Our patient has progressive chronic kidney disease due to AA amyloidosis. Her hematologist plans to reintroduce hydroxyurea at a lower starting dose. 


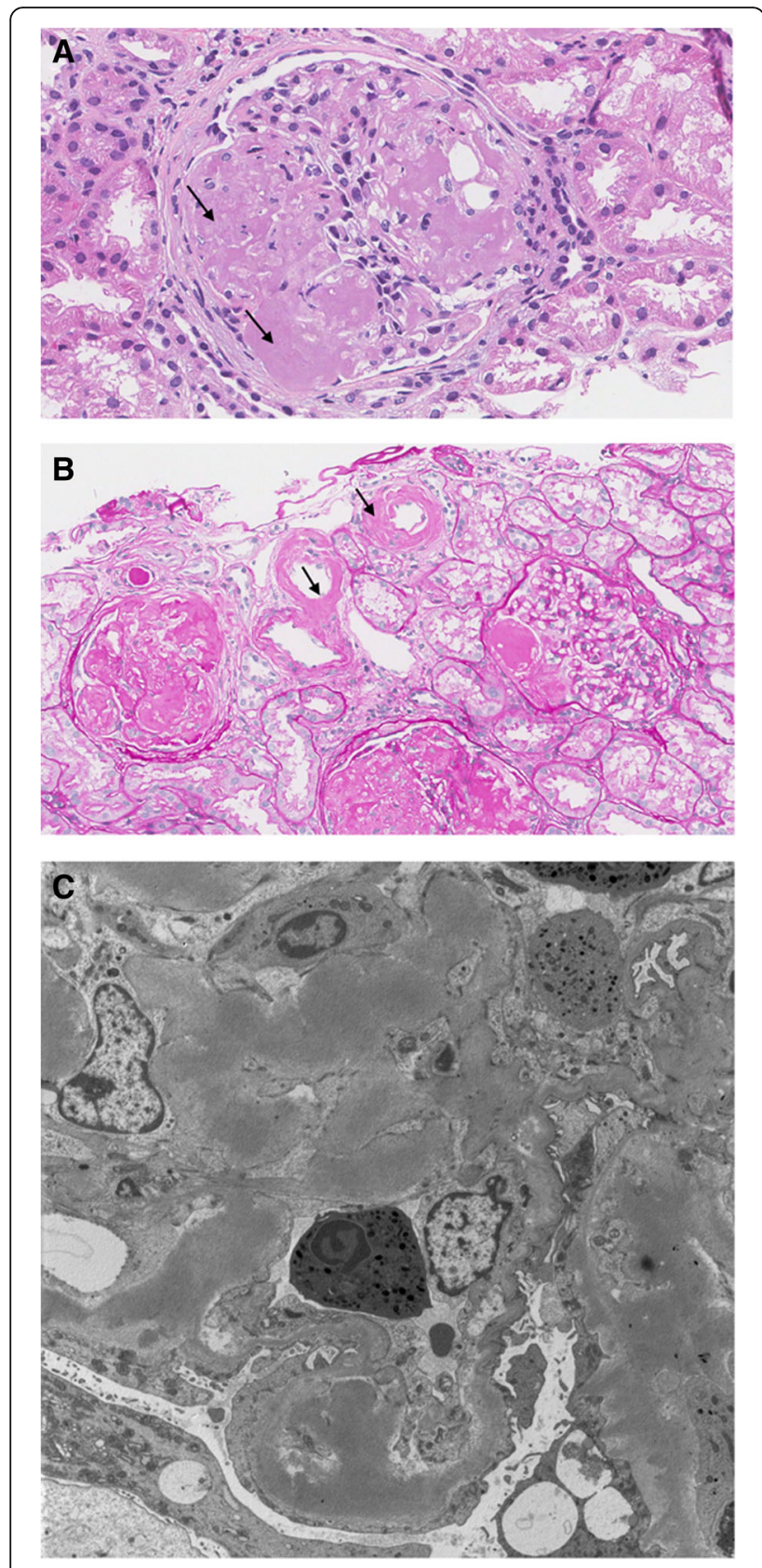

Fig. 1 Kidney biopsy specimen. a Hematoxylin and eosin stain (original magnification $\times 200$ ) with arrows pointing to nodular material consistent with amyloid

\section{Discussion and conclusions}

To our knowledge, this is the fifth report of AA amyloidosis among patients with homozygous sickle cell disease [2-5] and the first report with concomitant antibodies to double stranded DNA. AA amyloid protein, derived from serum amyloid A, is associated with chronic or recurring inflammation, such as found with chronic infection and rheumatic diseases. Recurrent vaso-occlusion with hypoxia and subsequent ischemia-reperfusion injury after resolution of vascular stasis, may lead to ongoing kidney inflammation and kidney injury in sickle cell disease [1]. It has been hypothesized that recurrent vaso-occlusive pain crises may lead to chronic inflammation, thereby leading to increase serum amyloid AA levels and ultimately leading to amyloid fibril formation $[2,5]$ but this is unclear. Furthermore, AA amyloidosis is associated with increased mortality, particularly if chronic kidney disease progresses to end-stage kidney disease [6].

Proteinuria in sickle cell disease increases with age [1] and is associated with hemolysis [7], as indicated by a lower hemoglobin level, higher LDH and higher reticulocyte count. Proteinuria is also associated with reduced GFR, as well as prior vaso-occlusive crisis, acute chest syndrome and pulmonary hypertension, all present in our patient [1]. Proteinuria was present in our patient 5 years prior to nephrology presentation but urine ACR values were not available again until 2 months prior to nephrology presentation, which prompted the nephrology referral. During the past 6 years, she has experienced multiple vaso-occlusive pain crises and acute chest syndrome and her estimated GFR has declined from 140 to 89 to $51 \mathrm{~mL} / \mathrm{min} / 1.73 \mathrm{~m}^{2}$ over 6 years. She may have had glomerular hyperfiltration when her estimated GFR was $140 \mathrm{~mL} / \mathrm{min} / 1.73 \mathrm{~m}^{2}$ and has now progressed to proteinuric chronic kidney disease due to AA amyloidosis. Although serum creatinine is an imperfect marker of glomerular filtration rate among patients with sickle cell disease because of increased tubular creatinine secretion [7], which is used in the CKD-EPI equation to calculate estimated GFR, this decline in estimated GFR is concerning. Preservation of kidney function may only be achieved by preventing further amyloid deposition into the kidneys. In AA amyloidosis, this requires control of the underlying disease, which in this case is sickle cell disease. Therapy that limits vaso-occlusive pain crises may limit further deposition of amyloid into the kidneys. Hydroxyurea, which induces fetal hemoglobin, is associated with decreased incidence of vaso-occlusive pain crises, number of red cell transfusions and proteinuria [8]. Angiotensin converting enzyme inhibitors are known to decrease proteinuria among patients with sickle cell disease and biopsy-proven glomerular enlargement and focal segmental glomerulosclerosis [9]. It is unknown whether ACE inhibition and hydroxyurea can reduce proteinuria or prevent worsening proteinuria in sickle cell disease with AA amyloidosis. Although initially unsuccessful, reintroduction of hydroxyurea at a lower starting dose may limit further vaso-occlusive crises and perhaps limit further AA amyloid deposition into the kidneys and progression of chronic kidney disease. Both hematology and nephrology teams felt that angiotensin converting enzyme inhibitor use was an unlikely contributor to our patient's worsening anemia so reassessment for perindopril 
use is planned. Further investigations will be warranted if her anemia worsens again since hematology did not believe that erythropoietin would be of benefit.

There was an additional rare discovery of antibodies to double stranded DNA without other features of SLE. Anti-nuclear antibody positivity has been described among patients in 10-19\% of patients with sickle cell disease compared with $0-2 \%$ of age- and sex-matched controls [10-13]. However, only $0-3 \%$ of these patients had antibodies to double stranded DNA. Although the presence of antibodies to double stranded DNA is only 73\% specific for a diagnosis of SLE [14], it may portend a future risk of developing SLE [15]. Therefore, careful follow-up of our patient for the development of SLE is also required.

In summary, AA amyloidosis can occur in sickle cell disease. This case report highlights several teaching points. This case emphasizes the importance of increased awareness among nephrologists for AA amyloidosis as a cause of proteinuria in sickle cell disease. Nephrotic-range proteinuria is uncommon in sickle cell disease and kidney biopsy is necessary for diagnosis. Sickle cell disease can cause chronic kidney disease with proteinuria, reduced glomerular filtration rate and is associated with increased mortality [1]. AA amyloidosis in sickle cell disease may be caused by frequent vaso-occlusive crises so their prevention is important. Although unstudied in sickle cell disease with AA amyloidosis per se, ACE inhibition and hydroxyurea decrease proteinuria so they may limit progression of chronic kidney disease $[8,9]$. Hydroxyurea decreases frequency of vaso-occlusive pain crises so it might be helpful in limiting progression of renal AA amyloidosis. However, further studies are needed to determine optimal treatment strategies for AA amyloidosis in sickle cell disease.

\section{Abbreviations}

ACR: Albumin to creatinine ratio; CKD-EPI: Chronic Kidney Disease Epidemiology Collaboration; GFR: Glomerular Filtration Rate; SCD: Sickle cell disease; SLE: Systemic lupus erythematosus

\section{Acknowledgments}

The authors thank Dr. Sohrab Ali for his contribution to image preparation for publication.

Availability of data and materials

All data generated are included in this article.

\section{Authors' contributions}

AB collected the data and wrote the manuscript. PB analyzed and interpreted the kidney biopsy images. EGC and MMS critically reviewed and provided an analysis of the nephrology issues in this case. All authors read and approved the final manuscript.

\section{Ethics approval and consent to participate} Not applicable.

\section{Consent for publication}

Written informed consent was obtained from the patient for publication of this Case Report and accompanying images.

\section{Competing interests}

The authors declare that they have no competing interests.

\section{Publisher's Note}

Springer Nature remains neutral with regard to jurisdictional claims in published maps and institutional affiliations.

\section{Author details}

'Division of Nephrology, Department of Medicine, The Ottawa Hospital and University of Ottawa, Riverside Campus, 1967 Riverside Drive, Ottawa, ON K1H 7W9, Canada. ${ }^{2}$ Department of Pathology, The Ottawa Hospital and University of Ottawa, General Campus, 501 Smyth Road, Ottawa, ON K1H 7W9, Canada.

Received: 14 December 2017 Accepted: 19 September 2018

Published online: 10 October 2018

\section{References}

1. Nath KA, Hebbel RP. Sickle cell disease: renal manifestations and mechanisms. Nat Rev Nephrol. 2015;11:161-71.

2. Win N, Brozovic M, Gabriel R. Secondary amyloidosis accompanying multiple sickle cell crises. Trop Dr. 1993;23:45-6.

3. Balal M, Paydas S, Seyrek N, Karayaylali I. Different glomerular pathologies in sickle cell anemia. Clin Nephrol. 2004;62(5):400-1.

4. Simsek B, Bayazit AK, Ergin M, Soran M, et al. Renal amyloidosis in a child with sickle cell anemia. Pediatr Nephrol. 2006;21(6):877-79.

5. Hadj Sadek B, Radoui A, Al Hamany Z, Benamar L, et al. L'amylose rénale: une complication inhabituelle de la drépanocytose. Med Trop. 201 1;71:185-6.

6. Lachmann HJ, Goodman HJB, Gilbertson JA, Gallimore JR, et al. Natural history and outcome in systemic AA amyloidosis. N Engl J Med. 2007;356: 2361-7.

7. Drawz P, Ayyappan S, Nouraie M, Saraf S, et al. Kidney disease among patients with sickle cell disease, hemoglobin SS and SC. Clin J Am Soc Nephrol. 2016;11:207-15.

8. Ware RE, de Montalembert M, Tshilolo L, Abboud MR. Sickle cell disease. Lancet. 2017;390(10091):311-23.

9. Falk RJ, Scheinman J, Phillips G, Orringer E, et al. Prevalence and pathologic features of sickle cell nephropathy and response to inhibition of angiotensinconverting enzyme. N Engl J Med. 1992;326:910-5.

10. Toly-Ndour C, Rouquette AM, Obadia S, M'Bappe P, et al. High titers of autoantibodies in patients with sickle cell disease. J Rheumatol. 2011; 38(2):302-9.

11. Abbas M, Bolad A, Rida M, Jiefri N. And Adil Mergani. Prevalence of antidouble stranded DNA among homozygous sickle cell disease in Sudan. Clinical Medicine and Diagnostics. 2013;3(4):75-81.

12. Quismorio FP Jr, Johnson C. Serum autoantibodies in patients with sickle cell Anemia. Amer J Med Sci. 1984;287(1):13-5.

13. Baethge BA, Bordelon TR, Mills GM, Bowen LM, et al. Antinuclear antibodies in sickle cell disease. Acta Haematol. 1990;84:186-9.

14. Haugbro K, Nossent JC, Winkler T, Figenschau Y, Rekvig OP. Anti-dsDNA antibodies and disease classification in antinuclear antibody positive patients: the role of analytical diversity. Ann Rheum Dis. 2004;63(4):386-94.

15. Arbuckle MR, McClain MT, Rubertone MV, Scofield RH, et al. Development of autoantibodies before the clinical onset of systemic lupus erythematosus. N Engl J Med. 2003;349(16):1526-33.

Ready to submit your research? Choose BMC and benefit from:

- fast, convenient online submission

- thorough peer review by experienced researchers in your field

- rapid publication on acceptance

- support for research data, including large and complex data types

- gold Open Access which fosters wider collaboration and increased citations

- maximum visibility for your research: over 100M website views per year

At BMC, research is always in progress.

Learn more biomedcentral.com/submissions 